
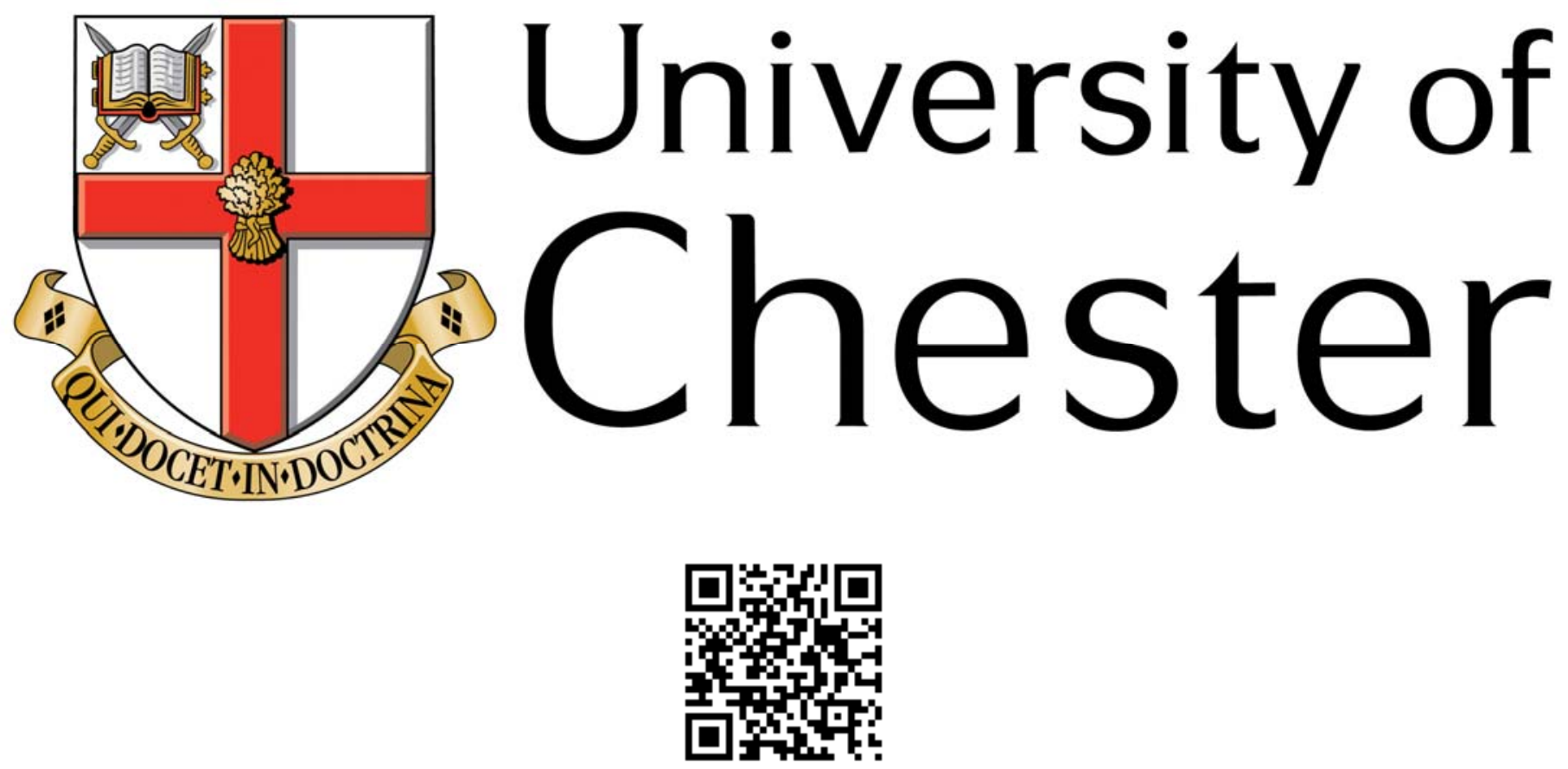

This work has been submitted to ChesterRep - the University of Chester's online research repository

\title{
http://chesterrep.openrepository.com
}

Author(s): David Clough

Title: On the relevance of Jesus Christ for Christian judgements about the legitimacy of violence - A modest proposal

Date: 2009

Originally published in: Studies in Christian Ethics

Example citation: Clough, D. (2009). On the relevance of Jesus Christ for Christian judgements about the legitimacy of violence - A modest proposal. Studies in Christian Ethics, 22(2), 196-207.

Version of item: Author's post-print

Available at: http://hdl.handle.net/10034/134372 
Clough, David. 'On the Relevance of Jesus Christ for Christian Judgements about the Legitimacy of Violence - A Modest Proposal' In Studies in Christian Ethics 22.2 (2009) 196-207.

[top of page 196]

\section{On the Relevance of Jesus Christ for Christian Judgements about the Legitimacy of Violence - A Modest Proposal}

The challenge of the task before us in determining the appropriate interpretation of the person, teaching and example of Jesus in relation to Christian judgements about the legitimacy of violence was aptly characterized by Helgeland, Daly and Burns in 1987:

[top of page 197]

Arguing from biblical and early church data, sometimes from precisely the same data, various authors have claimed support for almost every conceivable position from radical pacifism to holy war. Obviously something is wrong with the scholarship involved - unless one is prepared to accept that the NT is hopelessly contradictory and devoid of authority on this point. A further embarrassment for scholarship is that, in most cases, one need only know an author's confessional position in order to know the results of his or her analysis. ${ }^{1}$

We do well to bear such a warning in mind in our deliberations.

Unfortunately, it seems to me that the problem is still worse than this. The primary

problem is not that scholars examine the same data and come to different conclusions:

there is a prior issue that prevents the debate reaching even this stage. Most

discussions in the Christian tradition bypass the troubling task of interpreting how we

\footnotetext{
${ }^{1}$ John Helgeland, Robert J. Daly, and J. Patout Burns, Christians and the Military: The Early Experience (London: SCM Press Ltd, 1987), 10.
} 
might think about the legitimacy of violence in the context of the revelation of God in Jesus Christ. They do this by claiming on the basis of a wide variety of arguments that the aspects of this revelation that seem most germane to the question are irrelevant. As one who believes that the followers of Jesus Christ are called to eschew violence, this means that I cannot open a conversation with those who differ on the basis of how to interpret the teaching and example of Christ in relation to violence. To be fruitful, the debate must start much further back with the question of whether the teaching and example of Christ about violence is relevant to Christian thinking about violence. The modest proposal of this paper is that the teaching and example of Jesus Christ in relation to violence is relevant to Christian debates about the legitimacy of violence. While I hope this suggestion is not as monstrous as Swift's modest proposal that the Irish eat their children, from a survey of the tradition it seems almost as controversial. It seems to me therefore that much will be gained if we can establish this point. Most importantly, it would mean that we stand a chance of beginning a useful conversation between Christians about how we might interpret Christ's teaching and example. To this end I survey and critique some of the key arguments from the Christian tradition arguing against the relevance of Christ's teaching on violence, and then turn to some modern interpretations that take a similar line. ${ }^{2}$

\footnotetext{
${ }^{2}$ As Berkman and Hauerwas note, 'attempts to define "violence" outside of any context of language and culture-in-use must be considered sorely inadequate' (John Berkman and Stanley Hauerwas, 'Violence', in Dictionary of Ethics, Theology and Society, Paul Barry Clarke, and Andrew Linzey (eds.), (London: Routledge, 1996). Their point also alerts us to the fact that across the millennia my account of Christian thinking about the Sermon on the Mount surveys, the meaning of violence shifts. It would therefore be foolish to consider that we can begin with a definition of violence and discover whether various theologians believe it to be compatible with the Sermon on the Mount: if we were interested in definitions, we would do better to attend to what each thinker considers to be violent. My aim in this paper of highlighting the oddity of considering Jesus' teaching and example in this area to be irrelevant, however, requires no such fine-grained distinctions. The theologians I consider, Wink excepted, believe intentional killing of other human beings and warfare to be compatible with the teaching and example of Christ if the circumstances require them. Where I use 'violence' in this paper, therefore, I mean to include at least these practices, and note the need to be cautious about the transcultural and trans-historical applicability of the term to other practices.
} 
[top of page 198]

In a letter to Augustine in 421, Marcellinus quotes a Roman criticism of Christianity: it is a religion that is an enemy to Rome because its doctrine and preaching are inconsistent with the duties and rights of citizens. The critique cites the teaching of the Sermon on the Mount: not to retaliate, to turn the other cheek, to give away one's cloak if someone takes your coat, and to go a second mile if compelled to go one (Mt 5:38-42). In response to Marcellinus, Augustine begins by reminding the critics that many Roman authorities give the same advice about non-retaliation. But he goes on to argue that Marcellinus should not be concerned that the Sermon on the Mount is incompatible with Roman citizenship, because 'these precepts pertain rather to the inward disposition of the heart than to the actions which are done in the sight of men'. Inwardly we cherish patience and benevolence; outwardly we should do whatever will benefit our neighbour. ${ }^{3}$ While nourishing these inward dispositions, we must sometimes correct others, even against their wishes, with 'a certain benevolent severity', just as a father corrects his son by reluctantly inflicting pain on him. ${ }^{4}$ For Augustine, therefore, Jesus' teaching in the Sermon on the Mount concerns our inner life, and is irrelevant to the judgement that we sometimes have to use violence for the sake of those on whom we inflict it.

Aquinas agrees with the judgement that the teaching of the Sermon on the Mount is not relevant to the question of whether Christians should use violence. Citing Augustine, he claims that the instructions of Christ not to resist evil or revenge oneself 'must always be borne in readiness of mind, so that a man must always be prepared to refrain from resistance or self-defence if the situation calls for it'.

\footnotetext{
${ }^{3}$ Augustine, 'Epistle to Marcellinus' no. 138 (AD 412), in Nicene and Post-Nicene Fathers, Philip Schaff (ed.) (Buffalo: The Christian Literature Company: 1886), vol. 1, 2.13.

${ }^{4}$ Augustine, 'Epistle to Marcellinus', 2.14.
} 
Sometimes, however, for the common good or even for the good of his opponents he must act otherwise. ${ }^{5}$ Aquinas makes a similar point later when he judges it legitimate for a religious order to be directed to soldiering. Not resisting evil 'can pertain to perfection when it is necessary for the salvation of others' but the toleration of injuries done

[top of page 199]

to another 'is an imperfection, or even a sin, if one can readily restrain the wrongdoer'. Similarly, while one should not reclaim one's own possessions (following Lk 6:30), not reclaiming the property of another when obliged to do so is a $\sin ^{6}{ }^{6}$ For Aquinas, therefore, the teaching of the Sermon on the Mount is irrelevant whenever it comes into conflict with judgements about the welfare of others.

Martin Luther is sternly critical of those who attempt to water down the teaching of Jesus in the Sermon on the Mount, maintaining that these are commandments rather than merely counsels for those who would be perfect. As such, they apply to every person equally, and not just to a Christian elite. ${ }^{7}$ He then proceeds to divide humankind into two classes: the true Christians who belong to the kingdom of God, and the rest who belong to the kingdom of the world. Christians 'need no temporal law or sword' and if everyone were true Christians there would be no need for either. But true Christians are few in number, and those who belong to the kingdom of the world need to be restrained from evildoing, or the world would

\footnotetext{
${ }^{5}$ St. Thomas Aquinas, Summa Theologica (London: Blackfriars, 1963), II-II, 40, 1.

${ }^{6}$ Aquinas, Summa Theologica, II-II, 188, 3.

${ }^{7}$ Martin Luther, 'Temporal Authority: To What Extent it Should be Obeyed', in Luther's Works, vol.

45, Walther I. Brandt (ed.) (Philadephia: Fortress Press, 1962), 88.
} 
descend into chaos. ${ }^{8}$ Luther argues, therefore, that the command 'Do not resist evil' only applies to relations between Christians, and that Christians may and should become 'hangmen, constables, judges, lords, or princes' if there is a lack of them. This is not contrary to Jesus' command, he claims, because the Christian's wielding of the sword is to benefit their neighbour, rather than to protect themselves. ${ }^{9}$ Echoing Augustine, Luther harmonizes the Sermon on the Mount with a Christian use of violence by distinguishing between the inner life and outer actions of the Christian: 'at one and the same time you satisfy God's kingdom inwardly and the kingdom of the world outwardly. You suffer evil and injustice, and yet at the same time you punish evil and injustice; you do not resist evil, and yet at the same time, you do resist it. ${ }^{10}$ Again, Jesus' teaching is irrelevant to the Christian employment of violent actions that are necessary to preserve order.

John Calvin is still more permissive: the equity and moderation to which Christians are called in the Sermon on the Mount should not prevent Christians 'with entire friendship for their enemies' from protecting their own possessions through help from the magistrate, or out of 'zeal for the public interest', from calling 'for the punishment of the wicked and pestilential man, whom they know nothing will reform but death'. ${ }^{11}$ Again,

[top of page 200]

the Sermon on the Mount injunction to love one's enemies is no bar even to killing them.

\footnotetext{
${ }^{8}$ Luther, 'Temporal Authority', 88-91.

${ }^{9}$ Luther, 'Temporal Authority', 95.

${ }^{10}$ Luther, 'Temporal Authority', 96.

${ }^{11}$ John Calvin, Institutes of the Christian Religion, trans. Henry Beveridge (Grand Rapids, MI: Eerdmans, 1989), 4.20.20.
} 
Reinhold Niebuhr is the most prominent modern exponent of this interpretative line, and specifically the Lutheran form of it. The challenge to pacifism I take to be most acute in a Christian context is his essay 'Why the Christian Church is Not Pacifist', written in $1940 .{ }^{12}$ Niebuhr argues that the Christian gospel cannot be simply identified with the 'Law of Love', but must also take into account human sin. Most forms of modern pacifism are heretical, because they reject original sin and believe the absurd idea that perfect love will gain a simple victory over the world. Niebuhr considers attempts to defend Christian use of violence on the basis of Jesus' use of whips in the Temple or his instruction to his disciples to buy a sword to be 'pathetic': the demanding ethic of Jesus is both straightforwardly represented in the Sermon on the Mount and 'finally and ultimately normative'. ${ }^{13}$ But pacifists also dilute the teaching of Christ: what the Sermon on the Mount teaches is not nonviolence, but non-resistance. Once Christians recognize the impossibility of living out this Kingdom imperative in a sinful world, they appreciate their vocation for now is to resist evil, and in seeing this they recognize that the ultimate principles of the Kingdom of God cannot be interpreted as 'simple alternatives for the present schemes of relative justice'. ${ }^{14}$ Niebuhr claims to agree with pacifists in the judgement that the law of love remains relevant to human history: they 'hover over every social situation as an ideal possibility, ${ }^{15}$ but given that his Christian realism led him to judge that the atomic bombing of Hiroshima and Nagasaki by the United States could be justified, this hovering seems at quite some altitude. ${ }^{16}$ For Niebuhr,

\footnotetext{
${ }^{12}$ Reinhold Niebuhr, 'Why the Christian Church is Not Pacifist', in Christianity and Power Politics (Hamden, CT: Archon Books, 1969), 1-32.

${ }^{13}$ Niebuhr, 'Why the Christian Church is Not Pacifist', 7-8.

${ }^{14}$ Niebuhr, 'Why the Christian Church is Not Pacifist', 25.

${ }^{15}$ Niebuhr, 'Why the Christian Church is Not Pacifist', 25.

${ }^{16}$ Niebuhr's reaction to the atomic bombings of Japan was ambiguous. A few months after the bombings he wrote: 'Critics have rightly pointed out that we reached the level of Nazi morality in justifying the use of the bomb on the grounds that it shortened the war' (Reinhold Niebuhr, 'The Atomic Bomb', in Love and Justice: Selections from the Shorter Writings of Reinhold Niebuhr, ed.
} 
[top of page 201]

therefore, the Sermon on the Mount functions in characteristically Lutheran manner primarily to make clear the impossibility of abiding by Jesus' teaching before the Kingdom comes. Since we cannot live this way, Niebuhr's argument goes, we must find some more realistic way to engage with the world as it is, and at this point we step beyond what exegesis of texts can help us with.

For Augustine, Aquinas, Luther, Calvin and Niebuhr, therefore, the teaching of Jesus about violence is irrelevant to Christian judgements about the use of violence. A variety of reasons are given to support this judgement: Jesus' teaching is about the inner rather than the outer life; it is valid only when others are not involved; it relates only to relations between Christians; it is not valid in a sinful world like ours, but only when the kingdom comes. We must recognize that these judgements of the relevance of Jesus' teaching are made in the context of a conviction that other parts of the teaching of Christ require Christians to be violent. In particular, each of these authors share the conviction that Jesus' commands to love one's neighbour sometimes requires violent actions. What we have here, therefore, is a judgement that a particular interpretation of Jesus' teaching on love — love of neighbours necessarily means sometimes being violent — shows that Jesus' teaching on violence that contradicts this interpretation of neighbour love — don't resist evil, turn the other

D.B. Robertson (Louisville, KY: Westminster/John Knox, 1992), 233). But when the president of Harvard asked him to clarify his signature on a statement of Christian leaders criticizing the bombings, he wrote: 'I myself took the position that failing in achieving a Japanese surrender, the bomb would have had to be used to save the lives of thousands of American soldiers who would otherwise have perished on the beaches of Japan' (Reinhold Niebuhr, Letter to James B. Conant, March 12, 1946; reprinted in the appendix of James G. Hershberg, "Footnote on Hiroshima and Atomic Morality: Conant, Niebuhr, and an 'Emotional' Clergyman, 1945-46," SHAFR Newsletter, December 2002, available at http://www.shafr.org/newsletter/2002/dec/hiroshima.htm). For a discussion of Niebuhr's position, see David Clough and Brian Stiltner, Faith and Force: A Christian Debate About War (Washington, D.C.: Georgetown University Press, 2007), ch. 4. 
cheek, don't retaliate, love your enemies — is irrelevant to Christian judgements about the legitimacy of violence. It seems to me that we have grounds to prefer an interpretation of Jesus' teaching that does not depend on judging it contradictory, and does not require the judgement that where violence actions are addressed it should be considered irrelevant. This is the modest proposal of this paper, which I will now consider in the context of more recent discussions.

Helgeland, Daly and Burns, whose diagnosis of the problem of scholarly disagreement on this issue I began this paper with, support the idea that there is a tension or contradiction in Jesus' teaching at this point. They see impressive unanimity between Romans 12, Matthew 5 and Luke 6 on the Christian duty to love the enemy and not resist evil, but suggest that the equal commitment to a missionary love of the enemy that is almost aggressive makes clear that non-resistance is not an option and leads to an exegetical impasse. ${ }^{17}$ Progress beyond this impasse must be made with reference to other considerations, and their book emphasizes the choice of the church to justify the use of violence.

In his commentary on the first few chapters of Matthew, Ulrich Luz gives careful and sustained attention to the text of the Sermon on the Mount. ${ }^{18} \mathrm{He}$

[top of page 202]

is sensitive to the character of the actions Jesus prescribes in Mt 5:38-42 as 'conscious provocation' and 'symbolic protest' against oppression, and sees the actions as demanded by the coming of the kingdom: 'For Jesus, the arrival of the kingdom of God is manifested as limitless love of God for the people which on its

\footnotetext{
${ }^{17}$ Helgeland, Daly \& Burns, Christians and the Military, 15.

${ }^{18}$ Ulrich Luz, Matthew 1-7: A Commentary (Minneapolis: Augsburg, 1989), 337-51.
} 
part makes possible the love of humans among themselves and even for their enemies'. ${ }^{19}$ The renunciation of force called for by Christ is an expression of love for the neighbour, which 'must not be understood in a narrow sense, purely between people, but includes a protest against the force which rules the world and a breaking through the mechanisms of behaviour which are determined by it' ${ }^{20}$ But Luz believes that Jesus was mistaken about how the kingdom would come, and as a result his followers have had to work out a different way of remaining loyal to his teaching. In addition, he argues, the demands of Jesus 'were meant not as law but as examples and with the intent of leaving from the beginning room for creative fancy'. This means 'it is necessary on the basis of the exemplary nature of the text to take one's own situation into account' and Luz judges that the post-Constantinian history of interpretation of the text 'testifies to this necessity of change and the freedom which is given by the text itself. ${ }^{21}$ Luz judges that Jesus' teaching was meant for a reality different from the one in which we find ourselves. His view is distinct from those surveyed from points earlier in the tradition only in that he justifies the reinterpretation of the text as legitimated by the openness of the text itself to 'creative fancy'.

Dale Allison agrees with Luz that different contexts allow different readings of this section of the Sermon on the Mount:

Jesus and Matthew and the pre-Constantinian Christians were outsiders or belonged to minorities, as have most proponents of pacifism. Now outsiders and minorities are not, by definition, responsible for the institutions of society. This circumstance makes it easier for them to promulgate ideals that seemingly take little or no account of the conflicts that inevitably arise when the follower of Jesus becomes involved with such institutions. But others, in contrast to Jesus and Matthew, have found themselves both Christians and members of governmental organizations; and they have necessarily found new ways of understanding 5:38-42. Rather than condemning the exegetical

\footnotetext{
${ }^{19}$ Luz, Matthew 1-7, 328.

${ }^{20}$ Luz, Matthew 1-7, 328-9.

${ }^{21}$ Luz, Matthew 1-7, 335.
} 
changes brought by the Constantinian revolution we should regard them as inevitable and consistent with the fact that the Sermon on the Mount offers examples that call the moral imagination into play. ${ }^{22}$

[top of page 203]

For Allison the changed social location of the followers of Christ requires new ways of understanding the Sermon on the Mount. In justification of these innovations, in addition to citing Luz's view of the openness of the text he observes that if Matthew had meant to claim that Jesus enjoined pacifism, he would not have included 5:17-20, where the continuing force of Jewish law is affirmed. Allison also sees the commands of love of neighbour and love of enemy as creating conflicting responsibilities, with the implicit assumption that this conflict should be resolved in favour of the former. ${ }^{23}$

Luz and Allison stretch the meaning of 'interpretation' in suggesting that they are defending new ways of understanding the Sermon on the Mount rather than the setting aside of it. Yet we should be grateful that the judgement about the irrelevance of the text for the social location of modern Christians is here based in part on intratextual arguments: the character of the text as playful, fanciful, open and exemplary, and the supposed contradiction with the upholding of the law. There is a strong sense, however, that it is the violent actions they are convinced are necessary in a new social context that drives them to discover this fancy and play in the text. In relation to Allison's worry that to take 5:38-42 in their plain sense would contradict 17-20, it is not clear why we could not understand Jesus' teaching at this point as demanding more rigorous standards of behaviour within the framework of the law, in

\footnotetext{
${ }^{22}$ Dale C. Allison, The Sermon on the Mount: Inspiring the Moral Imagination (New York: Crossroad, 1999), 98.

${ }^{23}$ Allison, The Sermon on the Mount, 96.
} 
a similar way to the other antitheses, rather than as a contradiction of the law. ${ }^{24}$

Richard Horsley's argument for the view that the Sermon on the Mount is irrelevant to Christian judgements about the legitimacy of violence works is relates more closely to the text of the Sermon than any of the arguments surveyed thus far. His claim is that to use the 'love your enemies' sayings as the basis for pacifism or non-violence is to 'take them utterly out of their original context, both literarily and historically'. ${ }^{25}$ He argues that there is no evidence of any violent resistance movement at the time of Jesus, so interpreting 'do not resist evil' on the basis of such a context is illegitimate. Instead, we must recognize the "context was local interaction with personal enemies, not relations with foreign or other political enemies ${ }^{26}$ — it is only

[top of page 204]

the Matthean context that makes us think of the enemies as outsiders. ${ }^{27}$ The slap on the cheek which Jesus advised his followers not to respond to was simply a formal insult, rather than a truly violent act, and Horsley judges that nonviolence 'is neither the issue nor the message of these sayings' ${ }^{28}$ Horsley agrees with Luz and Allison that the text should not be taken as any kind of new law: instead, in a return to Augustine's line, the actions Jesus enjoins are 'focal instances' of a particular spirit or

\footnotetext{
${ }^{24}$ Richard Hays argues that most of the antitheses can be read as intensification rather than abrogation, but that Jesus' command not to resist an evildoer in the context of the law on punishment of offenders represents an undermining of the law (Richard Hays, B., The Moral Vision of the New Testament: Community, Cross, New Creation: A Contemporary Introduction to New Testament Ethics (Edinburgh: T\&T Clark, 1997), 324). This is an alternate response to Allison's worry: that any interpretation of 5:17-20 must reckon with significant developments in the understanding of the law Jesus commends.

${ }^{25}$ Richard A. Horsley, Jesus and the Spiral of Violence: Popular Jewish Resistance in Roman Palestine (San Francisco: Harper \& Row, 1987), 261.

${ }^{26}$ Horsley, Jesus and the Spiral of Violence, 266.

${ }^{27}$ Horsley, Jesus and the Spiral of Violence, 262.

${ }^{28}$ Horsley, Jesus and the Spiral of Violence, 267, 264.
} 
orientation towards one's circumstances. ${ }^{29}$

While it is refreshing to find any argument for the irrelevance of these texts based firmly within the text itself, Horsley's argument does not prove all it intends. In the first place, the fact that Jesus recommended the kinds of non-violent responses his audience were most likely to need in their local context does not provide evidence that in other (non-local?) contexts he would have suggested they respond violently. Second, the Matthean creation of the antitheses he posits strengthens rather than weaken the case that this teaching was understood by the Matthean community as instruction rather than merely 'focal instances' — Matthew deliberately placed the teaching in the context of the demands of the law. The fact that the actions described are examples rather than an abstract definition or an exhaustive catalogue does not detract from their being examples of a particular kind of response to provocation: i.e. a non-violent one. Third, Horsley does not suggest who in the local context might require one of Jesus' hearers to carry their pack for a mile, but it is hard to think of an alternative to one of the soldiers of the Roman occupying force. These might have been figures in the local context, but they were also clear political enemies in Horsley's sense (and Jesus'). Horsley advances our understanding of the passage in some ways, but his argument is not telling against my proposal that Jesus' teaching here is relevant in Christian discussions of violence. ${ }^{30}$

Examples of attempts to limit the implications of the Sermon from modern interpreters could be multiplied. Richard Hays cites Robert Guelich's argument that the injunction not to resist an evildoer should be interpreted as not going to court, but notes that the legal context does not fit with the other actions Jesus commends of

\footnotetext{
${ }^{29}$ Horsley, Jesus and the Spiral of Violence, 265.

${ }^{30}$ Richard Hays argues that there is nothing in the text to indicate that the context is local or that the enemies are not political (Hays, Moral Vision, 328).
} 
turning the other cheek, going the second mile and giving to all who ask. ${ }^{31}$

Walter Wink agrees with Niebuhr that Christians should be engaged in resisting evil, but disagrees that this is in contradiction to the Sermon on the Mount. He is concerned that the Sermon on the Mount has often been

[top of page 205]

used to stifle resistance to oppressive rule. Wink notes that the Greek word translated 'resist' is antistēnai: or anti-histemi - a verb which in its noun form means violent rebellion, armed revolt, or sharp dissension (Mt. 5:39). He considers that the translators of the King James Bible had an interest in enjoining passive non-resistance on the king's subjects, and concludes that 'A proper translation of Jesus' teaching would then be, "Do not strike back at evil (or one who has done you evil) in kind. Do not give him blow for blow. Do not retaliate against violence with violence.",32 Wink is convinced that the actions enjoined in the Sermon on the Mount of turning the other cheek to provoke a more disrespectful attack, stripping naked when sued by a creditor for your outer garment, and offering to carry a Roman soldier's pack an illegal second mile, were all creative non-violent strategies for those with very little power to resist those who oppressed them. Jesus' teaching was therefore a third way, providing an alternative to the more obvious options of passivity or violence as a response to injustice. $^{33}$

Winks's interpretation of these texts is not without its problems. Willard Swartley notes that the category of a creative response to oppression does not fit so

\footnotetext{
${ }^{31}$ Hays, Moral Vision, 325-6.

${ }^{32}$ Walter Wink, 'Jesus' Third Way' in Roger S. Gottlieb (ed.), Liberating Faith: Religious Voices for Justice, Peace, and Ecological Wisdom (Lanham, MD: Rowman and Littlefield, 2003), 442.

${ }^{33}$ Walter Wink, 'Jesus' Third Way', 442-5.
} 
well with the last two examples of Christian action Jesus gives in the Sermon: giving to beggars and not refusing loans. Swartley prefers Schottroff's depiction of the refusal to retaliate and love of enemies as 'the prophetic proclamation of the approaching sovereignty of God' ${ }^{34}$ While Wink wishes to steer interpretation of these texts away from an abstract prohibition on the use of violence and towards the exemplification of creative resistance, I noted above that the examples cited are all of a particular kind: non-violent ones.

Like Augustine, Aquinas, Luther, Calvin and Niebuhr, the modern interpreters I have cited, with the exception of Wink, seek to make the teaching of the Sermon on the Mount irrelevant for reflection on the use of violence in a modern context. Their discussions stand in a closer relation to the biblical text than those earlier in the tradition, and they suggest a new array of reasons why the texts should be considered irrelevant - Christians now find themselves in different social contexts; the instructions were only meant to apply to village squabbles; they related only to a legal context - but the conclusions are the same: we know on other grounds that violence is necessary, and therefore this teaching must not be relevant to the context we confront.

The discussion I have traced has focussed on the interpretation of the Sermon on the Mount in particular, with references to the similar emphasis

[top of page 206]

in Romans 12:14-21. This focus has been necessary on grounds of space, but clearly this is not the only locus for a discussion of the teaching and example of Christ. Aside

\footnotetext{
${ }^{34}$ Willard M. Swartley, Covenant of Peace: The Missing Peace in New Testament Theology and Ethics (Grand Rapids, MI: Eerdmans, 2006), 63-4.
} 
from the attempts Niebuhr characterizes as 'pathetic' that draw broad and contradictory conclusions from Jesus' cleansing of the Temple (Mk 11:15-19 and parallels) or the odd instruction to the disciples to buy a sword ( $\operatorname{~k2} 22: 3$ ), there is a broad consensus about Jesus' attitude to violence: in his teaching, and perhaps even more clearly in his life and death, he proclaimed a mode of response to evil that rejected confronting it with violence. It is not only the Sermon on the Mount that is judged irrelevant to Christian discussions about the legitimacy of violence, therefore, but the entirety of the teaching and example of Christ as it pertains to this question. My brief survey has shown that from Augustine onwards, Christians have taken the view that the consistent teaching and example of Christ about the use of violence cannot be squared with the necessity of being violent in the context in which they find themselves. For the many and varied reasons I have listed, the teaching and example of Christ about the use of violence by his followers are dismissed as irrelevant. Instead, the church has decided it must be guided by other lights: by a reasonable estimation of what it takes to maintain order people being what they are. This view of the relevance of Jesus' teaching and example is demoralizing in both senses for modern Christians attempting to relate the New Testament to their practice. It posits a fundamental discontinuity between the teaching of Jesus Christ and the life to which his followers are called. It casts Christians adrift from all moorings that might guide their moral lives, and requires that they take their bearings in open water from what seems necessary in the midst of a sinful world. It is also theologically problematic in its judgement that modern Christians live in an epoch that is discontinuous with that of Jesus' first followers: rather, Christians in the first and twenty-first centuries both belong to the theological era between the resurrection of Christ and his return and there is therefore no basic discontinuity in the mode of life 
to which they are called.

[top of page 207]

Most of all, the argument that the teaching and example of Christ in relation to violence is irrelevant to the question about whether violence is legitimate proves too much. It is not just pacifism that falls when the teaching of the gospel are overridden by the demands of the moment: any kind of moral restraint of violence is vulnerable once we have come to the judgement that Jesus' teaching on this topic must be set aside. Augustine defended the torture of prisoners by Christian magistrates and the coercion of the Donatists to bring them to faith in his day; Thomas Aquinas judged that religious orders should fight in the Crusades as instruments of a divinely imposed penance on those who occupied the Holy Land; and Reinhold Niebuhr defended the atomic bombing of Hiroshima and Nagasaki as a way of saving the lives of American servicemen. These judgements are possible only once it has been decided that the followers of Jesus Christ must live their lives guided by standards other than those taught and exemplified by their saviour. In the hope of a change of heart on this matter, I submit that the church will decide best about the legitimacy of violence when it recognizes that the teaching and example of Jesus Christ are relevant to the question, and I look forward to the time when a debate is possible on that basis. 